\title{
Buddhism, Poststructuralist Thought, Cultural Studies A Profession of Faith
}

\section{EDWIN NG}

DEAKIN UNIVERSITY

The declaration of the one who professes is a performative declaration in some way. It pledges like an act of sworn faith, an oath, a testimony, a manifestation, an attestation, or a promise, a commitment. To profess is to make a pledge while committing one's responsibility. 'To make profession of' is to declare out loud what one is, what one believes, what one wants to be, while asking another to take one's word and believe this declaration.

Jacques Derrida ${ }^{1}$

This is a profession of faith. For three years, I have been researching Buddhism and poststructuralist theories on knowledge, self and ethics in order to articulate the ethico-political implications of my practice of Vipassana (a form of Buddhist meditation) and interrogate what is called the politics of spirituality. ${ }^{2}$ Propelling this autoethnographic project is a question of faith. Yet, I've been uncomfortable and afraid of articulating this outright. Why? Much of the discomfort stems from the tensions constituting my subjectivity as a religiously committed Buddhist 
attempting to understand my faith with and through the secular discourses of cultural studies. Perhaps I'm afraid of the disapproval, or even ridicule I might face in professing the religious inspiration I bring to and discover through academia. But can't this commitment to knowledge also be hospitable to faith, and therefore the possibility that religion or spiritual pursuits may have crucial things to say about those conundrums we grapple with, like ethics, (inter)subjectivity and the body? In tackling these conundrums with Buddhism and poststructuralist thought, I find it irresponsible to pretend that faith does not also support my practice of cultural studies. Hence, by way of an analysis this essay makes a profession of faith.

The essay first contextualises the discursive fields shaping this profession before analysing Vipassana with a 'religious' Foucauldian approach oriented around the critico-political aims of his late work. This will elucidate how Buddhist and poststructuralist thought share certain concerns, and identify trajectories for further inquiry. The primary aim is to explore the role of faith within cultural studies, if not the academy more generally. My understanding of faith is partly informed by Buddhism, but I do not conflate faith with institutional or doctrinal religious commitment. ${ }^{3}$ Rather, I'm adopting a deconstructive strategy to decentre this reductionistic understanding of faith, exploring it as an affective response that is irreducible to any ontotheological proposition, and which reverberates through the hopes and aspirations of 'believers' and 'nonbelievers' alike. Hence, a preestablished definition of faith is suspended in favour of a hypothetical question. Recognising its resonance with affirmations of relationality like 'trust', 'confidence' and 'fidelity', I ask: 'Might it be that faith is betrothed to an open question, the movements of an ongoing task?'

\section{-CONTEXTUALISING THE PROFESSION}

Vipassana serves as a case study, but it is not representative of Buddhism as a whole, which far from being a monolith involves a diversity of knowledge practices from different sociocultural contexts. Nonetheless, it does reflect distinctive trends of 'Buddhist modernism', an ongoing process whereby the varied forms of Buddhism are attuned to the cultural and intellectual understandings of its historical milieu. Developing out of this process are detraditionalised and demythologised representations of Buddhism that emphasise the ethical and philosophical over the 
religious, and foreground meditation as a central practice. ${ }^{4}$ Vipassana is one such representation. 5 While it shares the doctrinal lineage of Theravada Buddhism (practiced predominantly in Sri Lanka and Southeast Asia), its founder S.N. Goenka disavows the label 'Buddhism', describing the Buddha's teaching as 'the art of living' and meditation as a 'non-sectarian technique' of 'self transformation through selfobservation'.6 My research is situated on the same historical continuum of Buddhist modernism and aims to elucidate the contributions of Buddhism to current ethicopolitical issues with Foucauldian critique, thereby extending upon existing scholarship that focuses on Buddhist and Derridean philosophy.7 In particular, it uses Vipassana to build on studies of the 'religious' dimensions of Foucault's work. ${ }^{8}$

Jeremy Carrette argues that Foucault had always been concerned, if only implicitly, with the intersections between religion and culture, unearthing in his oeuvre 'spiritual corporality' and 'political spirituality', the twin modalities of Foucault's 'religious question'. Spiritual corporality turns on Foucault's analysis of the body as both the effect and vehicle of power. This, Carrette contends, eliminates the persistent theological dualism of soul and body, spirit and matter, such that religious ideas 'become ways of expressing the body which can be both a technology of domination and a more positive technology of self.$^{9}$ Political spirituality, on the other hand, turns on Foucault's working definition of spirituality as 'a subject acceding to a certain mode of being', 10 and is described by him as 'the will to discover a different way of governing oneself through a different way of dividing up true and false'.11 Political spirituality facilitates the interrogation of 'the government of truth'. For Carrette, it cross-modulates the 'spiritual', 'ethical', and 'political' with 'truth', 'subjectivity' and 'power',12 functioning as both an analytical tool and strategy of self-constitution for negotiating the politics of subjectivity: as both 'subject to someone else by control and dependence', and an 'identity by a conscience and self-knowledge'.13 While there is a decisive shift from 'power' to 'subject' and 'ethics' in his late work, 'Foucault does not abandon politics to dedicate himself to ethics, but complicates the study of governmentalities through the exploration of the care of the self ... ethics, or the subject, is not thought of as the other of politics or power'.14

The Foucauldian knowledge-power-subjectivity schema is of course widely adopted in cultural studies' interdisciplinary investigations of the micro-politics 
constituting everyday life, including, but not limited to, the discourses and practices of consumer culture. My work adapts the approaches developed in this strand of cultural studies, particularly those that do not focus exclusively on the ideological imperatives circumscribing popular cultural formations but also explore their counter-hegemonic potentials and/or contributions to academia. ${ }^{15}$ Religion and spirituality, however, have not been treated with the same hospitality. Where attention is given to them, studies have tended to view them with suspicion, adapting for instance Nikolas Rose's Foucauldian-inflected thesis about the 'psy matrix' to criticise them as the technologies of neoliberal governmentality (though it is worth noting that Rose himself cautions against performing only sceptical or paranoid assessments). ${ }^{16}$ Jay Johnston and Ruth Barcan have identified limitations with such studies. ${ }^{17}$ They ask if they mire cultural studies in 'the programmatic pessimism of Foucauldian accounts of selfhood', if their 'foundational secularism' marginalises 'both the bodily experiences and the concepts of the body' found in religion and spirituality, which could in fact enrich critical inquiries. ${ }^{18}$ Hence, they propose 'augmentation and enrichment' to the Foucauldian approach ('in ways that do not so much contradict it as shift its analytical focus') to enable 'a rethinking of notions of spirit', the 're-theorising [of] the mind/body split and the nature of matter'.19

My analysis of Vipassana adopts the 'religious' Foucauldian approach outlined above which offers a way forward that is mindful of the corporeality and critical contributions of religious or spiritual knowledge practices. This approach doesn't neglect or contradict criticisms of the neoliberal imperatives circumscribing 'spirituality', an important political intervention that must be sustained. In this regard, Guy Redden's contribution to this issue of Cultural Studies Review presents a cogent argument for developing research on the market logics shaping the knowledge production of New Age spirituality and its impact on broader questions about religion and society. ${ }^{20}$ The analysis of Vipassana will foreground the ethics of cultural studies and extrapolate on how it involves faith. Here, a deconstructive strategy becomes crucial. Joanna Zylinska has elaborated from the premises of 'performativity' and 'undecidability' a two-pronged argument: that 'the political commitment of cultural studies already works against a certain normative horizon', and that 'its numerous acts of political practice simultaneously perform, propose and 
develop an ethics of cultural studies'.21 Refracting Levinasian ethics through Derrida's arguments about possible-impossible aporias like l'avenir and messianicity, Zylinska articulates cultural studies as a 'responsible response' that adopts a foundational aim of responding to difference and to what calls for recognition and respect. As 'an ethical opening to incalculable alterity', it is 'a project-in-the-making, on its way', and can 'never be properly founded'.22 She thus characterises cultural studies in Derridean terms as 'a promise ... a messianic project of awaiting the unknown and the not-yet, of opening ourselves not only to the differences we already know and can name but also to those that remain unnameable and unidentifiable, to what may yet surprise and scare us' $^{\prime 23}$

Zylinska doesn't broach the topic of faith, but the aporias she engages with are the same ones informing Derrida's argument about a 'fiduciary act' between faith and knowledge, religion and reason, about the impossibility of placing one before the other. ${ }^{24}$ If knowledge is always-already marked by the trace of faith, is a responsible response-the promise of cultural studies-an impassioned call for and of faith, or at least a more hospitable encounter with faith? What if the movement of faith indeed accompanies and spurs us on to do what we do?

\section{-ARTS OF LIVING}

Vipassana is premised on the Buddhist concept of vipassanā, meaning 'to see things as they are' or 'insight'. The meditator first develops awareness of breathing to cultivate what is called mindfulness, an attitudinal and perceptual practice of equanimous attentiveness. The meditator then turns awareness towards the body to contemplate on vedanā, a term connoting both 'bare feelings' (what I interpret in current theoretical terms as affect) and physical sensations, the latter serving as the primary object of meditation. With mindfulness the meditator perceives various sensations throughout the body, even very subtle ones that weren't apparent before. Goenka claims that sensations can neither be controlled nor willed. Hence, one should not seek any particular sensation but recognise that all sensations-which according to Buddhist scriptures are experienced either as pleasant, unpleasant or neutral-arise only to pass away.

Vipassana provides a means for understanding in and through the body the interrelated Buddhist doctrines of anicca (impermanence/change), dukkha 
(existential discontent) and anattā (not-self). The doctrines posit that existence is impermanent because all conditions pass away when their supporting conditions change. If all phenomena are contingent upon other phenomena ad infinitum, presence can never be fully secured nor can any phenomenon be said to have an intrinsic essence, especially the self, hence not-self-which, given a Derridean gloss, regards the transcendental subject as a trail of ungraspable traces of traces. Goenka claims that the failure to fully recognise the reality of impermanence and concomitant delusions about an enduring self-essence (including the belief in an enduring, originary soul-essence) perpetuates existential discontent. Therefore, the crux of Vipassana is to cultivate equanimity so as to relinquish the futile craving for, and aversion towards, whatever threatens fixity in one's life and the obstinate desire for self-presence. Goenka constantly reminds students to neither relate to pleasantness with craving nor unpleasantness with aversion, enjoining them to always 'start again' without frustration whenever attention wavers from the task at hand. With equanimity, one would perceive with increasing clarity the body as a field of changing sensations, developing at the same time a different relationship to thoughts, which reveal themselves to be just as ephemeral and insubstantial. Goenka illustrates the everyday effects of the practice with the following scenario.

Consider how we tend to lose our temper when confronted with a difficult situation, even though we tell ourselves we shouldn't. Often, we even project our displeasure onto others or external situations. Vipassana teaches that every emotional-mental state has concomitant bodily sensations. Mindfulness would allow one to observe the sensations (of heat, for instance) accompanying anger and cultivate insight into the self 'as it is': an impersonal interplay of perception, affect, sensation, and thought conditioned by prior experience and not as 'I', 'me' or 'mine'to again give this a Derridean gloss, the processes constituting the body-mind are recognised as endlessly differing and deferring. In other words, we'd see that there is no need to react angrily because there is no necessity or inevitability for 'anger' or the self-identity of 'angry person'. Inasmuch as we maintain a degree of mindfulness and equanimity, we enact freedom, clearing a space for becoming otherwise.

Granted, the relationships between perception, affect, sensation, thought and selfhood could be more complex than is suggested here. But I want to stay with Goenka's scenario to explore the affinities between Vipassana and Foucauldian 
thought. Vipassana appears to exemplify what Foucault examines in his late work on the Classical Greek ideal of an art of living: technologies of the self, knowledge practices that 'permit individuals to effect by their own means or with the help of others a certain number of operations on their own bodies and souls, thoughts, conduct, and ways of being, so as to transform themselves in order to attain a certain state of happiness, purity, wisdom, perfection, or immortality'. ${ }^{25}$ What points of consonance might a Buddhist art of living share with a Foucauldian-inflected one?

Timothy O'Leary has argued that Foucault's 'genealogy of ethics' seeks to inaugurate new modes of being which might displace existing relationships between truth, power and subjectivity. ${ }^{26}$ Building on Foucault's fourfold analysis of ethical substance, mode of subjection, ethical work and telos-the 'what', 'why', 'how' and 'goal' of ethics-0'Leary makes the following proposals for a contemporary art of living. ${ }^{27}$ First, insofar as Foucault's 'critical attitude' regards the subject as no more than a 'fictitious unity', much like how 'sex' is no more than an 'ideal point' consolidated by the discourses of sexuality, the ethical substance is the transcendental subject which must be refused. ${ }^{28}$ Second, if the self is not a product but a process, the mode of subjection is the recognition that the unknown openendedness of existence has to be embraced with an attitude that treats life as an art of ongoing crafting. Third, insofar as Foucault's critico-political project aims 'to prise open the relations of truth-power-subjectivity which makes us the kind of individual that we are', the ethical work involves practices of desubjectivation. ${ }^{29}$ Fourth, if the task of critique is not to remove constraint or domination but to continuously open up possibilities for new sociopolitical choices and relations, the telos is freedom, conceived not as an historical constant or ideal state but as constituted by relations, as the capacity to say no to a certain identity or to be governed a certain way: the freedom to always become otherwise.

Following Foucault's re-evaluation of the precept of 'the care of self' in the history of Western thought, O'Leary offers philosophy-as-a-way-of-life as one technique for a contemporary art of living. ${ }^{30}$ But given that Foucault identifies spiritual askesis as a modality of the care of self, Vipassana could be another technique. ${ }^{31}$ Treating subjectivity as a process, Vipassana shares Foucault's aim of 'refusing the self'. Moreover, insofar as mindfulness enables a different relationship to thought it is consonant with Foucault's understanding of critique, which 'consists 
in seeing what kinds of self-evidences, liberties, acquired and non-reflective modes of thought, the practices we accept rest on'.32 Foucault says: 'Criticism consists in ... showing that things are not as obvious as we might believe, doing it in such a way that what we accept as going without saying no longer goes without saying.'33 What is rendered difficult to 'go without saying' in Vipassana is the notion of an unchanging 'I', and if, as David Hoy suggests, Foucault's critico-political aim is to bring people up against 'a limit-experience that disrupts their deepest convictions and sense of who they are', Vipassana is geared towards a similar goal, revealing the body-mind to be always already liminal: anicca and anattā.

Vipassana can therefore be read as a practice of desubjectivation. Foucault describes the desired effect of desubjectivation as se dépendre de soi-même, an expression usually translated as 'distancing oneself from oneself' or 'detaching oneself from oneself', though Hoy renders it as 'dissolving oneself'. ${ }^{34}$ This coincides with Vipassana where it is said that with finely honed mindfulness and equanimity the perceived solidity of the body would dissolve into a boundless field of vibrations, a direct intuition of anicca and anattā that would radically re-orientate one's subjectivity. It is difficult, if not impossible, to objectively validate this claim. Regardless, the general aim of Vipassana to disrupt delusions about an enduring self-essence is consonant with the Foucauldian aim of 'dissolving oneself'.

Another point of consonance is their non-essentialising approach to freedom. While Buddhist discourses position nibbāna (Sanskrit: nirvāna) or Awakening as an end to strive for, they also mitigate against any essentialising understanding of the goal. Hence, Goenka cautions that while Awakening involves full liberation from dukkha, to crave or harbour expectations about it is to set oneself in the opposite direction. Awakening is thus suspended-like a 'perhaps'-in favour of an ongoing process of transforming one's life with Buddhist ethical precepts and practice. Like Foucault's critico-political project, Vipassana pursues freedom as a 'continuous practice of an art of living'.35 The ceaseless movement of anicca (impermanence/change) and the 'not' of anattā (not-self) suggest that what Buddhist practice requires is a kind of waiting directed not at any particular object but for the 'outside': reality 'as it is' with which language may perhaps never know or be certain if it coincides. Foucault's musing about language offers a fitting allegory 
for the practice of mindfulness, the Buddhist commitment to unconditionally Awaken to reality 'as it is':

Language in its every word, is indeed directed at contents that preexist it; but in its own being, provided that it holds as close to its being as possible, it only unfolds in the pureness of the wait. Waiting is directed at nothing: any object that could gratify it would only efface it. Still, it is not confined to one place, it is not a resigned immobility; it has the endurance of a movement that will never end and would never promise itself the reward of rest; it does not wrap itself in interiority; all of it falls irremediably outside. Waiting cannot wait for itself at the end of its own past, nor rejoice in its own practice, nor steel itself once and for all, for it was never lacking courage. What takes it up is not memory but forgetting. This forgetting ... is extreme attentiveness. 36

Vipassana involves equanimous attentiveness towards the liminality of the bios, a practice described as 'the art of living'. Foucault's critical ontology of the present involves extreme attentiveness towards the 'limits of ourselves',37 a practice prompting these comments about an aesthetics of existence: 'The idea of the bios as a material for an aesthetic piece of art is something which fascinates me.'38 To these ends, this short analysis has outlined how a 'religious' Foucauldian approach could mobilise practices like Vipassana as ethically and politically enabling rather than politically conservative or ideologically complicit-and I hope it has opened lines of dialogue between cultural studies, Buddhist communities and scholarship, and religion more generally. But to engage in dialogue questions about faith cannot be ignored, not if we are to make a responsible response towards religion.

\section{-AWAITING IN FAITH, PERHAPS?}

If an art of living is an ongoing task, is this commitment to always become otherwise also a commitment to what Derrida calls l'avenir, the absolute future to come, to which we can only say yes, 'yes' to the 'perhaps'? In discussing what comes before (but not in any temporal sense) religion and reason, Derrida paints this arresting image: 'an abyss ... a desert in a desert, there where one neither can nor should see coming what ought or could-perhaps-be yet to come'.39 Might this be the 
pureness of the wait Foucault alludes to? A call for and of faith? Perhaps? Derrida says:

This experience of the 'perhaps' would be that of both the possible and impossible, of the possible as impossible. If all that arises is what is already possible, and so capable of being anticipated and expected, that is not an event. The event is possible only coming from the impossible. It arises like the coming of the impossible, at the point where a perhaps deprives us of all certainty and leaves the future to the future. This perhaps is necessarily allied to a yes: yes, yes to whoever or whatever comes about. ${ }^{40}$

'Perhaps' bridges the space between the possible and the impossible, or what Caputo explicates as the future present and the absolute future. The future present refers to the momentum of the present towards a future we can reasonably anticipate; hence we maintain a savings account. The absolute future, however, is the unforeseeable future that shatters 'the comfortable horizons of expectation that surround the present'. ${ }^{41}$ Unlike the future present, it offers no horizon for orienting our calculations or expectations. The absolute future makes all knowledge of what might be possible impossible, impossible because it is wholly outside the order of what can be reasonably anticipated. Yet, this unforeseeable future to come is the condition of possibility for calculations or expectations-for any decision. Thus, every decision cannot but admit undecidability, always given up and over as a pledge (of faith?) to the absolute future to come, l'avenir, the impossible.

The aporetic logic of l'avenir (and messianicity discussed below) informs Caputo's conceptualisation of a 'religious sense of life' demanding nothing less than faith, love, and hope. By 'the religious', Caputo is not referring to (but doesn't exclude) organised religion. Rather, 'the religious' refers to 'a basic structure of our lives ... that should be placed alongside very basic things, like having an artistic sense or political sense'. ${ }^{42}$ Martin Hägglund has questioned Caputo's deconstructive approach to 'God', arguing that he removes the condition of radical evil which Derrida refuses to do, and that his interpretation of 'religion without religion' misreads Derrida's ideas which point rather to a 'radical atheism'. ${ }^{43}$ This debate is important for clarifying 'the religious turn' in critical thought, but it is beyond the purview of this essay. In any event, it needs to be examined alongside ongoing inquiries into how an unreflexive deployment of a religion-secular dichotomy 
blindsides current thinking to the conceits of secularism, a task requiring sustained collective effort, as this special issue of Cultural Studies Review hopes to encourage. I nevertheless highlight Hägglund's quarrel with Caputo's work to point out that radical atheism still involves faith. Hägglund himself says, 'We can never know for sure what will happen because experience is predicated on the unpredictable coming of time. Whatever we do, we place faith in a future that may shatter our hopes and lay waste what we desire.'44 Might it be, then, that faith is irreducible to any ontotheological proposition, an affective response that reverberates through the hopes and aspirations of 'believers' and 'non-believers' alike? I'll return to this question later. Consider for the moment what Derrida says:

My own understanding of faith is that there is faith whenever one gives up not only any certainty but also any determined hope. If one says that resurrection is the horizon of one's hope then-since one knows what one names when one says 'resurrection'-faith is not pure faith. It is already knowledge ... That is why you have to be an atheist of this sort [someone who 'rightly passes for an atheist'] in order to be true to faith, to pure faith. 45

Faith, in and of the 'perhaps', reverberates through my coterminous practice of Buddhism, poststructuralist thought and cultural studies, all of which demand openness to unknowingness, an openness enacted by both Derrida's and Foucault's work. Insofar as Foucauldian critique performs a 'hermeneutics of refusal' that refuses to answer the question 'Who am I?' in any determinate way and challenges those who would enforce their answers on others, Foucault arguably shares Derrida's appreciation of unknowingness and the desire to keep the future open. As Caputo suggests, Foucault's critico-political aims echo Derrida's messianic affirmation of viens, oui, oui, come, yes, yes. ${ }^{46}$

Derrida's conceptualisation of the messianic, informed in part and subversively by his own Jewish heritage, affirms incalculable alterity. The messianic or 'messianicity without messianism' refers to 'the opening to the future or to the coming of the other as the advent of justice, but without horizon of expectation and without prophetic prefiguration ... At issue there is "a general structure of experience".'47 The messianic does not belong properly to the Abrahamic religions nor does it require a Messiah, for to give it specific content is to circumscribe it 
within a determinable horizon that the absolute future makes impossible. Messianicity is not a horizon but the shattering of the horizon. ${ }^{48}$ For Derrida, this 'abstract messianicity belongs from the very beginning to the experience of faith, of believing, of a credit that is irreducible to knowledge and of a trust that "founds" all relation to the other in testimony'. ${ }^{49}$ In Spectres of Marx, he speaks of the affinity between Marx's messianic spirit and deconstruction's affirmation of unconditional justice to come as 'the movement of an experience open to the absolute future of what is coming, that is to say, a necessarily indeterminate, abstract, desert-like experience that is confided, exposed, given up to its waiting for the other and for the event'.50

We return to the pureness of the wait, the desert in a desert: there where one neither can nor should see coming what ought or could-perhaps-be yet to come (where Derrida and Foucault gaze together towards the impossible horizon with unknowingness, and perhaps, faith?) There, too, a messianic cultural-studies-in-themaking awaits patiently as a promise, a responsible response in the face of incalculable alterity, standing resolute on a 'double vector decision' involving attentiveness towards those marginalised others it engages with, and continuous reexamination of its own commitments and exclusions. ${ }^{51}$ An approach to cultural studies driven by an ethical imperative to always 'start again', as Goenka might say, implicitly echoes Derrida's arguments about the scriptural story of Abraham: that the 'ethical can ... end up making us irresponsible', that every response towards the other always sacrifices 'other others'-tout autre est tout autre, every other (one) is every (bit) other. ${ }^{52}$ Derrida writes:

The simple concepts of alterity and of singularity constitute the concept of duty as much as that of responsibility. As a result, the concepts of responsibility, of decision, or of duty, are condemned to paradox, scandal, and aporia. Paradox, scandal, and aporia are themselves nothing other than sacrifice, the exposition of conceptual thinking at its limits, at its death and finitude. As soon as I enter into a relation with the other, with the gaze, look, request, love command, or call of the other, I know that I can respond only by sacrificing ethics, that is, by sacrificing whatever obliges me also to respond, in the same way, in the same instant, to all the others. ${ }^{53}$ 
If responsibility always involves 'irresponsibilisation', then any ethical or political decision cannot be taken once and for all but must be continuously reviewed, retaken. ${ }^{54}$ As Derrida says, 'there would be no decision, in the strong sense of the word, in ethics, in politics, no decision, and thus no responsibility, without the experience of some undecidability ... a decision has to go through some impossibility in order for it to be a decision.' 55 Hence, cultural studies as a messianic project has to constantly double back on undecidability, returning again and again to the pureness of the wait, the desert in a desert: there where one neither can nor should see coming what ought or could-perhaps-be yet to come.

'Perhaps'-traces of which mark this profession, traversing the art of living, anicca, anattā, mindfulness, waiting, l'avenir, messianicity, come, yes, yes-may perhaps be the most responsible response: 'There is no future and no relation to the coming of the event without experience of the "perhaps".'56 A messianic culturalstudies-in-the-making would strive to take into account 'the whole spectrum of possibilities and occurrences, the horizon of which is always partially occluded by what we could describe as the "spectre of the perhaps"'.57 This is important: embracing the indeterminacy of the perhaps does not imply paralysis. As Derrida says, 'If no decision (ethical, juridical, political) is possible without interrupting determination by engaging oneself in the perhaps ... the same decision must interrupt the very thing that is the condition of possibility: the perhaps itself.'58 Zylinska thus argues that cultural studies has to 'remain open to the possibility of its pervertibility, collapse, annihilation, and withering down', and inasmuch as its ethical engagement is performative, our critico-political interventions (academic publications and conferences, engagements with consumer practices, cultural policy studies and so on) have to be accompanied by a form of delay or deferral, an openness to the unknown. 59 This invitation to openness recalls the arts of living where delay or deferral accompanies and sustains the pursuit of freedom, which embraces the unknown to perform the possibility for new sociopolitical choices and relations, for becoming otherwise, for Awakening. Zylinska writes:

It is in this very openness to the unknown, to the forms of political engagement that cannot yet perhaps be described in the language of cultural theory, sociology, ethnography or any other more established disciplinary discourses, that cultural studies becomes intrinsically ethical 
... For Derrida messianic politics constitute a viable political option arising out of the renunciation of a desire to rule, control and master; it is a politics which does not compromise its commitment even if it does leave a specific agenda behind. What we are left with are 'ways of respecting or greeting what remains to come-a future of which we know nothing. What comes will never belong to the order of knowledge or fore-knowledge'. 60

We return yet again to the pureness of the wait, the desert in a desert: there where one neither can nor should see coming what ought or could-perhaps-be yet to come. A call for and of faith? Perhaps, 'faith without faith', where 'undecidability is the first, last and constant, the element, the space in which faith makes its leap, the horizon in terms of which faith understands its limits, understands that it is faith, through a trace darkly'?61

My coterminous practice of Buddhism, poststructuralist thought and cultural studies has made this question of faith impossible to ignore, impossible not to say yes, yes to the perhaps, not if I wish to maintain fidelity to undecidability, anicca, impermanence, change, which admittedly can and has aroused fear and trembling; but I cannot keep silent because it also arouses, perhaps it is even the condition of possibility for, trust, confidence, hope, and yes, love. Consider this leitmotif-?!?!?!in Thai Buddhist artist, the late Montien Boonma's work. Boonma, who lost his wife to breast cancer in 1994 and succumbed to brain tumour himself in 2000, confronted through his art dukkha, the uncertainties of life that is anicca. ?!?!?! (the interrobang) was even plastered on the walls of his dying wife's hospital room, representing his experience of Buddhist meditation, of the unknown, surprise, discovery, hope-the movement of faith:

The question mark is the symbol of the unknown realisable through meditation. The spiral shape of the question mark represents the movement from the outer to the inner (and vice versa) achieved by concentration. When we grasp the unknown, we feel it but cannot express it. The exclamation mark is a symbol of this feeling of realisation. I perceived a gap between these two ... the question and the response these ... two are never ending. A response can turn into the subsequent question. It's like our mind. ${ }^{62}$ ?!?!?!... 
My point here is not to make claims about the unknown that is realisable by the mind but to propose that faith is, to paraphrase Boonma, what we feel but cannot ever fully express. Given the inroads made into the study of affect in the past decade, could this be one way forward: to investigate faith as something felt, of the nonrational (which is not to say irrational) in tension with-or perhaps in a mutually supportive relationship with-the rational? This suggestion is prompted partly by my experience of Buddhist soteriology as an ongoing process of embodying 'inbetween-ness', which coincides with the characterisation of affect as 'born in inbetween-ness'; 63 and partly by Brian Massumi's observation that 'faith' forms the 'ultimate foundation of the capitalist monetary system'.64 Investigating faith with affect theory could therefore not only illuminate the affective dynamics of religious commitment and spiritual pursuit, but also uncover new strategies for contesting neoliberal politics, which arguably functions like a religion of the market. To again evoke Redden's essay, how, for example, might we investigate the question of faith within the context of New Age spirituality, and what might the question elucidate about its affective economy? Such a critical hospitality towards spiritual knowledge practices and faith performs a double vector decision, a responsible response towards this 'other' that is religion and cultural studies' 'long-standing commitment to the applied critique of the social and political effects of a market economy', a commitment which, Graeme Turner argues, ought to remain a foundational stance even as we explore how the ever-proliferating products and practices of the market might empower individuals. At the very least, I'd suggest that this broadly Marxist commitment ought to be a central axis for orienting the general task of responding to difference. 65

Faith as an affective response born in in-between-ness? This inquiry is certainly pertinent in the case of Vipassana as it prioritises vedanā. But it could also be explored in the contexts of other religions or spiritualities and even nonreligious contexts like academia, where faith may very well be the 'ultimate glue' that holds together our hopes and aspirations as we engage in the (endless?!?!?!) pursuit of understanding, helping us adhere to our ethico-political commitments with fidelity, with trust and confidence in our practice, vocation, craft, calling: our profession. Perhaps this could be one way of redressing the neglect of faith in cultural studies, if not the academy more generally? 
In conclusion, I offer Boonma's motif as a visual metaphor for the movement of thought, a ceaselessly differing and deferring trail of ?!?!?! that always keeps faith with undecidability, the perhaps. ?!?!?! represents the profession I'm making in the name of 'cultural studies', a promise, a messianic project 'which renounces the desire to know, to close off dissensus, to erase incalculable alterity, but which does not at the same time sidestep its political commitment, presents itself as both an ethical possibility and a responsibility'.66 This is my profession of faith. This profession, I accept, remains indeterminate, uncertain. But perhaps this is precisely why it is a profession of faith?!?!?! I do not pretend to have my finger on faith, quite impossible to speak about, much less know. I thus offer this profession of faith to you, whom I can only ever address in good faith, as an invitation to ponder together on the 'perhaps', which, I believe, we (forgive me for being presumptuous) cannot but feel in this profession, in this very life.

Yours faithfully.

Edwin Ng works in the School of Communication and Creative Arts at Deakin University. His current research performs autoethnographical investigations of his coterminous practice of Buddhism and cultural research so as to explore hospitable encounters between sacred and scholarly traditions, and to interrogate ethicopolitical debates about religion, spirituality, and the role of faith in cultural studies and micropolitics more generally.

\footnotetext{
-AcKNOWLEDGEMENTS

I thank all who have generously offered feedback on this essay. This profession of faith is dedicated to loved ones, friends, colleagues and other others who remain unknown, without whom this performative declaration would not be possible.
} 
-NOTES

1 Jacques Derrida, 'The Future of the Profession or the University without Condition (thanks to the “Humanities", what could take place tomorrow)' in Jacques Derrida and the Humanities: A Critical Reader, ed. Tom Cohen, Cambridge University Press, Cambridge, 2001, pp. 35-6.

2 Jeremy Carrette and Richard King, Selling Spirituality: The Silent Takeover of Religion, Routledge, New York, 2005.

3 My experience of Buddhism suggests that faith is linked with ethics, a link also found in Derrida's work. See Edwin Ng, 'Cultural Studies and Matters of Faith: The Case of DhammaWheel.com', Cultural Studies Review, vol. 17, no.1, 2011, pp. 247-69.

${ }^{4}$ See for instance: David McMahan, The Making of Buddhist Modernism, Oxford University Press, Oxford and New York, 2008; Donald S. Lopez Jr, Buddhism and Science: A Guide for the Perplexed, University of Chicago Press, Chicago, 2008; Donald S. Lopez Jr (ed.), Curators of the Buddha: The Study of Buddhism Under Colonialism, Chicago University Press, Chicago, 1995; Robert Sharf, 'Buddhist Modernism and the Rhetoric of Meditative Experience', Numen 42, 1995, pp. 228-83.

5 Such representations of Buddhism have accrued much cultural cachet in late-capitalist societies, prompting Slavoj Zizek to question the ideological implications of 'Western Buddhism'. My investigation into the ethico-political potentials of Vipassana articulates a response to his claim that the Buddhist meditative stance 'enables you to fully participate in the frantic pace of the capitalist game while sustaining the perception that you are not really in it'. See Slavoj Zizek, On Belief, Routledge, New York, 2001, pp. 12-15.

6 Vipassana Meditation, 'What is Vipassana?', <http://www.dhamma.org/en/vipassana.shtml>.

${ }^{7}$ See for example, Jin Y. Park (ed.), Buddhisms and Deconstructions, Rowman and Littlefield, Lanham, 2006.

${ }^{8}$ Michel Foucault, Religion and Culture, edited by Jeremy Carrette, Routledge, New York, 1999; Jeremy Carrette, Foucault and Religion: Spiritual Corporality and Political Spirituality, Routledge, London and New York, 2000; James Bernauer and Jeremy Carrette (eds), Michel Foucault and Theology: The Politics of Religious Experience, Ashgate, Aldershot, UK and Burlington, USA, 2003

${ }^{9}$ Carrette, Foucault and Religion, p. 126.

10 Michel Foucault, 'The Ethic of the Care of the Self as a Practice of Freedom', in The Final Foucault, ed. James Bernauer and David Rasmussen, MIT Press, Cambridge, Mass., 1988, p. 14.

11 Michel Foucault, 'Questions of Method' in The Foucault Effect: Studies in Governmentality, with two lectures by and an interview with Michel Foucault, ed. Graham Burchell, Colin Gordon, and Peter Miller, University of Chicago Press, Chicago, 1991, p. 82.

12 Carrette, Foucault and Religion, p. 138.

13 Michel Foucault, 'The Subject and Power', Critical Inquiry, vol. 8, no. 4, 1982, p. 781. 
14 Frédéric Gros, 'Course Context' in Michel Foucault, The Hermeneutics of the Subject: Lectures at the Collège de France 1981-1982, ed. Frédéric Gros, trans. Graham Burchell, Picador, New York, 2005, p. 512.

15 For a sample of such approaches, see 'Introduction' in Matt Hills, Fan Cultures, Routledge, London and New York, 2002.

16 Nikolas Rose, Governing the Soul: The Shaping of the Private Self, Routledge, London, 1990; Nikolas Rose, Inventing Our Selves: Psychology, Power and Personhood, Cambridge University Press, Cambridge, 1998.

17 Jay Johnston, and Ruth Barcan, 'Subtle Transformations: Imagining the Body in Alternative Health Practices', International Journal of Cultural Studies, vol. 9, no. 1, 2006, pp. 26-8.

18 Jay Johnston and Ruth Barcan, 'The Haunting: Cultural Studies, Religion, and Alternative Practices', The Iowa Journal of Cultural Studies, vol. 7, 2005,

<http://www.uiowa.edu/ ijcs/secular/barcan_johnston.htm>.

19 Johnston and Barcan, 'The Haunting'. See also, Ruth Barcan, 'Alternative Therapies as Disciplinary Practices: The Uses and Limitations of a Foucauldian Approach' in Cultural Theory in Everyday Practice, ed. Nicole Anderson and Katrina Schlunke, Oxford University Press, Melbourne, Australia, 2008.

20 Guy Redden, 'The Secret, Cultural Property and the Construction of the Spiritual Commodity', Cultural Studies Review, vol. 18, no. 2, 2012, pp. 52-73.

21 The focus here is on undecidability; the reader is referred to Zylinska's book for clarification on her treatment of performativity. Joanna Zylinska, The Ethics of Cultural Studies, Continuum, London; New York, 2004, p. 4.

22 Zylinska, p. 35.

23 Zylinska, p. 39.

24 Jacques Derrida, 'Faith and Knowledge: The Two Sources of "Religion" at the Limits of Reason Alone' in Acts of Religion, ed. Gil Anidjar, Routledge, London and New York, 2002, pp. 40-101.

25 Michel Foucault, 'About the Beginnings of The Hermeneutics of the Self: Two Lectures at Dartmouth', Political Theory, vol. 21, no. 2, 1993, p. 203.

26 Timothy O'Leary, Foucault and the Art of Ethics, Continuum, London and New York, 2002.

27 Michel Foucault, The Use of Pleasure, Vintage Books, New York, 1990, pp. 25-32.

${ }^{28}$ Michel Foucault, History of Sexuality, Vintage Books, New York, 1990, pp. 154-5.

29 O'Leary, p. 153.

${ }^{30}$ Foucault notes that up till the Cartesian moment when they were decisively split, 'know thyself' was not only twinned with but subordinated to 'the care of self'. Michel Foucault, The Hermeneutics of the Subject: Lectures at the Collège de France 1981-1982, ed. Frédéric Gros, trans. Graham Burchell, Picador, New York, 2005, pp. 1-24.

${ }^{31}$ Foucault, The Hermeneutics of the Subject, pp. 15-16. 
32 Michel Foucault, 'Is It Really Important to Think? An Interview Translated by Thomas Keenan', Philosophy and Social Criticism, vol. 9, no. 1, 1982, p. 33. Robert Hattam's discussion of Foucault's work alerted me to this consonance between Buddhist mindfulness and the Foucauldian critical attitude; see Robert Hattam, Awakening Struggle: Towards a Buddhist Critical Social Theory, Post Pressed, Queensland, 2004, pp. 46-8, 110-3.

33 Foucault, 'Is It Really Important to Think?', p. 34.

34 David Couzens Hoy, Critical Resistance: From Poststructuralism to Post-Critique, MIT Press, Cambridge, MA, 2005, p. 90.

35 O'Leary, p. 173

36 Michel Foucault, 'Maurice Blanchot: The Thought from Outside' in Foucault/Blanchot, trans. Brian Massumi, Zone Books, New York, pp. 55-6; see also Thomas Flynn, 'Partially Desacralized Spaces: The Religious Availability of Foucault's Thought' in Michel Foucault and Theology: The Politics of Religious Experience, ed. James Bernauer and Jeremy Carrette, Ashgate, Aldershot, UK and Burlington, USA, 2003, pp. 143-55.

37 Michel Foucault, 'What is Enlightenment?' in The Foucault Reader: An Introduction to Foucault's Thought, ed. Paul Rabinow, Penguin, London, 1984, p. 46.

38 Michel Foucault, 'On the Genealogy of Ethics: An Overview of Work in Progress' in The Foucault Reader, p. 348.

39 Derrida, 'Faith and Knowledge', p. 47.

40 Jacques Derrida, Paper Machine, trans. Rachel Bowlby, Stanford University Press, California, 2005, p. 74.

${ }^{41}$ Caputo, On Religion, p. 8; see also John D. Caputo, The Prayers and Tears of Jacques Derrida: Religion Without Religion, Indiana University Press, Bloomington, Indiana, 1997, pp. 69-87.

42 John D. Caputo, On Religion, Routledge, London, 2001, p. 8-9.

${ }^{43}$ Martin Hägglund, Radical Atheism: Derrida and the Time of Life, Stanford University Press, Stanford, California; London, 2008, pp. 116-28.

44 Hägglund, p. 126.

45 Jacques Derrida, 'Terror, Religion, and the New Politics' in Debates in Continental Philosophy:

Conversations with Contemporary Thinkers, ed. Richard Kearney, Fordham University Press, New York, pp. 12-13.

46 John D. Caputo, 'On Not Knowing Who We Are: Madness, Hermeneutics and the Night of Truth in Foucault' in Michel Foucault and Theology: The Politics of Religious Experience, ed. James Bernauer and Jeremy Carrette, Ashgate, Aldershot, England and Burlington, USA, 2003, p. 128.

47 Derrida, 'Faith and Knowledge', p. 56.

48 Caputo, The Prayers and Tears, p. 118.

49 Derrida, 'Faith and Knowledge', p. 56. 
50 Jacques Derrida, Spectres of Marx: The State of Debt, the Work of Mourning, and the New International, trans. Peggy Kamuf, Routledge, New York, p. 90.

51 Zylinska, pp. 35-6.

52 Jacques Derrida, The Gift of Death, trans. David Wills, University of Chicago Press, Chicago, 1995, p.

61.

53 Derrida, The Gift of Death, p. 68.

${ }^{54}$ For a discussion on 'irresponsibilisation', see the chapter 'Derrida's Ethics of Irresponsibilization' in J. Hillis Miller, For Derrida, Fordham University Press, New York, 2009.

55 Jacques Derrida, 'Hospitality, Justice and Responsibility: A Dialogue with Jacques Derrida' in Questioning Ethics: Contemporary Debates in Philosophy, ed. Richard Kearney and Mark Dooley, Routledge, London; New York, 1999, p. 66.

56 Derrida, 'The Future of the Profession', p. 54.

57 Zylinska, p. 37.

58 Jacques Derrida, The Politics of Friendship, trans. George Collins, Verso, London and New York, 1997, p. 67.

${ }^{59}$ Zylinska, p. 36. For a recent example of how this openness is enacted towards questions about 'the sacred', see Lyn McCredden, Luminous Moment: The Contemporary Sacred, ATF Press, South Australia, 2010.

60 Zylinska, p. 39.

61 Caputo, The Prayers and Tears, p. 63.

62 Quoted in Apinan Poshyananda, Montien Boonma: Temple of the Mind, Asia Society, New York, 2003, p. 29.

63 Gregory J. Seigworth and Melissa Gregg, 'An Inventory of Shimmers' in The Affect Theory Reader, ed. Melissa Gregg and Gregory J. Seigwort, Duke University Press, Durham and London, 2010, p. 2.

64 Brian Massumi, Parables for The Virtual, Duke University Press, Durham and London, 2002, p. 44.

65 Graeme Turner, 'Surrendering the Space: Convergence Culture, Cultural Studies, and the Curriculum', Cultural Studies, vol. 25, no. 4-5, 2011, p. 688. Marx's oft-cited remark about religion as the opium of the people notwithstanding, when read in the broader context of his writings on religion Marxist critique of social injustice may not be as antithetical to religion's concern with ameliorating human suffering as widely assumed. See Christopher J. Roberts, 'On Secularization, Rationalization, and Other Mystical Things: The Unfinished Work of Marx's Religious Criticism', Iowa Journal of Cultural Studies vol. 7, 2005, <http://www.uiowa.edu/ ijcs/secular/roberts.htm>.

66 Zylinska, p. 39. 